Authors' Contribution:

A Study Design

B Data Collection

C Statistical Analysis

D Data Interpretation

E Manuscript Preparation

F Literature Search

G Funds Collection

\section{Temporal-spatial orientation in first- grade pupils from elementary school participating in Physical Education classes using Edubal educational balls}

\author{
Sara Wawrzyniak ABcdefg, Andrzej Rokita Aefg, Damian Pawlik Bef \\ Department of Team Games, University School of Physical Education in Wroclaw, Poland
}

abstract

Background The aim of the study was to determine the level and changes in the level of temporal-spatial orientation in first-grade pupils from elementary schools who participated in Physical Education classes integrated with subject-related contents that used Edubal educational balls.

Material/Methods

Results

Conclusions

Key words

\section{article details}

Article statistics

Full-text PDF:

Copyright

Indexation:

Funding:

Conflict of interest: Corresponding author:

Open Access License:
Research material comprised first-grade pupils from two classes in an elementary school in Wroclaw, Poland. The study was carried out during the second term of the 2013/2014 school year. Fifty-four pupils ( 26 girls and 18 boys) were diagnosed in total. The study employed the method of a pedagogical experiment that used the parallel groups technique (experimental class and control class).

In the first examination, pupils from the control group obtained better results compared to pupils from the experimental group $(p=0.04)$. In the second examination, pupils from the experimental class obtained better results compared to those from the control group. However, the difference between the results obtained in both groups was not statistically significant $(p=0.87)$.

The results obtained in the study lead to a conclusion that it is justified to carry out further studies in order to evaluate the level and possible changes in temporal-spatial orientation in first-grade pupils from elementary school who participate in Physical Education classes that use Edubal educational balls and to search for the relationships between the pupils' temporal-spatial orientation and school performance.

temporal-spatial orientation, first-grade pupils, elementary school, Edubal educational balls.
Word count: 2,994; Tables: 2; Figures: 4; References: 63

Received: December 2014; Accepted: May 2015; Published: June 2015

http://www.balticsportscience.com

(๑) Gdansk University of Physical Education and Sport, Poland

Celdes, CNKI Scholar (China National Knowledge Infrastructure), CNPIEC, De Gruyter - IBR (International Bibliography of Reviews of Scholarly Literature in the Humanities and Social Sciences), De Gruyter - IBZ (International Bibliography of Periodical Literature in the Humanities and Social Sciences), DOAJ, EBSCO - Central $\&$ Eastern European Academic Source, EBSCO - SPORTDiscus, EBSCO Discovery Service, Google Scholar, Index Copernicus, J-Gate, Naviga (Softweco, Primo Central (ExLibris), ProQuest - Family Health, ProQuest - Health \& Medical Complete, ProQuest - Illustrata: Health Sciences, ProQuest - Nursing \& Allied Health Source, Summon (Serials Solutions/ProQuest, TDOne (TDNet), Ulrich's Periodicals Directory/ulrichsweb, WorldCat (OCLC)

The study was carried out within the research project: „Graphomotor skills, eye-hand coordination and temporalspatial orientation in first-grade pupils from elementary school participating in Physical Education classes with Edubal educational balls"

Authors have declared that no competing interest exists.

Sara Wawrzyniak, University School of Physical Education, Department of Team Sports, A. Mickiewicza Str. 58 , 51-684 Wroclaw, Poland; phone: +48 604536 348; fax: +48 7134735 62; e-mail: sara.wawrzyniak@yahoo.com This is an open access article distributed under the terms of the Creative Commons Attribution-Non-commercial 4.0 International (http://creativecommons.org/licenses/by-nc/4.0/), which permits use, distribution, and reproduction in any medium, provided the original work is properly cited, the use is non-commercial and is otherwise in compliance with the license. 


\section{INTRODUCTION}

The beginning of education in first-grade classes of elementary schools is a particularly important period in children's development, who familiarize with the world of learning at school. Early school education represents a specific foundation which further education and raising children rest upon [1]. The role of school and teachers is to support pupils in their proper and comprehensive intellectual, emotional, social, ethical, physical and aesthetic development [2].

In early school education, pupils are in the period of younger school age, which is when children obtain the best results in motor learning [3]. Achieving an adequate level of motor abilities supports the learning process in first-grade pupils. Studies have demonstrated a relationship between pupils' motor skills and cognitive development. It was found that a high level of motor skills improves their school performance [3-25].

In first-grade classes of elementary schools, pupils start learning to read and write. These skills are especially important from the standpoint of the educational process since difficulties in this area might cause school failure $[6,26-34]$. Therefore, disturbances in motor skills, particularly in spe-cific coordination motor abilities and, more specifically, temporal-spatial orientation, might be a cause of school failure in learning to read and write.

Temporal-spatial orientation is one of specific coordination motor abilities which control human movements. It is often understood to mean feeling the distance from an object [35]. This ability allows for adoption of human body position and changes in this position during movement of the whole body in time and space with respect to a specific area of activity (e.g. a sports field, sports hall or a sports device) or a moving object (a partner, an opponent, the ball), combining perception and motor activity [36].

Temporal-spatial orientation allows not only for normal functioning in everyday life, but it always affects the process of learning at school. It determines the speed and the quality of learning as well as the accuracy of learning to read and write [3, 4, 37, 38]. Wojcik-Grzyb [4] argues that learning reading and writing skills is not only an intellectual but also a motor activity. Zurek [38] emphasizes that the development of higher writing skills is stimulated by the somatic and motor development. A low level of temporal-spatial orientation might directly cause difficulties in acquisition of reading and writing skills.

It was demonstrated that a change in the level of temporal-spatial orientation can be stimulated. The level of temporal-spatial orientation depends on interactions between biological and environmental factors and, according to many authors, on using the respective methods and training resources [39-44]. It seems that the best method of development of temporal-spatial orientation in pupils at the early school age is the use of games and play with the ball during Physical Education classes. In first to third grade classes, children are willing to perform various motor exercises and to compete, which is connected with more intensive motor activity and biological need for „blowing off steam” [45]. At this stage of education, games and play are an inseparable component of physical activity classes. Furthermore, games 
and play are a favourite form of physical activity among children and young people [46-48]. One of the didactic resources that match the canons of early school education is Edubal educational balls. Edubal educational balls is a set of 94 balls used for mini team games (basketball, football, volleyball, handball), in four colours, with painted letters of alphabet (large and small letters), digits from 1 to 9 and 0 , mathematical operation symbols and a symbol of electronic mail "@” [49]. Edubal educational balls are included in the list of didactic resources for the use in schools during general education and integrated education at the level of elementary school (No. 1566/2003, based on the ordinance of the Ministry of National Education and Sport, Journal of Laws of 2009, No. 69, Pos. 635). Educational balls were also given a recommendation of the Sejm Committee for Physical Culture and Sport (hearing as of 25th November 2003, Bulletin No. 2552/IV).

The use of Edubal educational balls in Physical Education classes does not only make the classes attractive but also improves their efficiency in acquisition of cognitive skills in the field of Polish language and mathematical skills [50-57].

The aim of the study was to determine the level and changes in the level of temporal-spatial orientation in first-grade pupils from elementary schools who participated in Physical Education classes integrated with subject-related contents that used Edubal educational balls. We asked the following research questions:

1. What is the level of temporal-spatial orientation in first-grade pupils from elementary school (experimental class and control class)?

2. Did (how) the level of temporal-spatial orientation change in first-grade pupils who participated in Physical Education classes integrated with subject-related contents using Edubal educational balls (experimental classes) and pupils from the control group who participated in Physical Education classes without using Edubal educational balls?

3. Do Physical Education classes using Edubal educational balls differentiate between the level of temporal-spatial orientation in first-grade pupils from elementary schools?

4. Does (how) gender differentiate between the level of temporal-spatial orientation in first-grade pupils from elementary school?

\section{MATERIALS AND METHODS}

Research material was first-grade pupils from two classes of the Elementary School No. 50 in Wroclaw, Poland, aged 6 to 7 years. The study was carried out at the end of the first and second term of the 2013/2014 school year. Fifty four pupils ( 26 girls and 28 boys) participated in the study. Twenty eight pupils (16 girls and 12 boys) formed the experimental group whereas the control group was comprised of 26 pupils (10 girls and 16 boys). The study used the methodology of pedagogical experiment carried out using parallel group technique carried out in natural conditions and the method of individual cases (in the case of 4 pupils aged 6). 
Pedagogical experiment was carried out from January to June 2014 during the second term of learning at school. The first term of learning was adopted as equalization of educational opportunities in all children. The first term of learning was aimed at introduction of children into the world of learning at school, familiarizing with a new environment and equalization of varied level of knowledge and school skills. The first term of learning was aimed at introduction of children into the world of learning at school, familiarizing with the new environment and equalization of the varied level of knowledge and school skills. An experimental factor was represented by a curriculum for Physical Education classes integrated with subject-related contents that used Edubal educational balls. Physical Education classes in the experimental group were carried out twice a week after 45 minutes using Edubal educational balls, whereas in the control group, the classes were carried out without using the balls. The dependent variable in the experimental group was level of temporalspatial orientation in first-grade pupils from elementary school.

The level of temporal-spatial orientation was evaluated with a use of modified Reactive Shuttle Drill test by Pawlik et al. [59] and the Fusion Smart Speed System (Fusion Sport, Coopers Plains, QLD, Australia) (Fig. 1). The system is used in the certified Ball Games Research Laboratory in the Chair of Team Games at the University of Physical Education in Wroclaw, Poland, with a certificate of the Quality Management System (PN-EN ISO 9001:2009).

The modified Reactive Shuttle Drill test by Pawlik et al. [59] consisted in running 5 randomly chosen sections as fast as possible from the Smart Jump reaction mat to the gate indicated with a light column and a light reflector. The test started when a subject stepped on the Smart Jump mat and then the light in the randomly chosen gate column went on. The subject ran to the gate, crossed the line marked with a tape with both feet and then ran back to the mat. This pattern was repeated 5 times. Each student performed the test twice. The apparatus measured time with accuracy of 0.001 second and the result was averaged to $0.01 \mathrm{~s}$. Statistical analysis was based on the better results of the two tests.

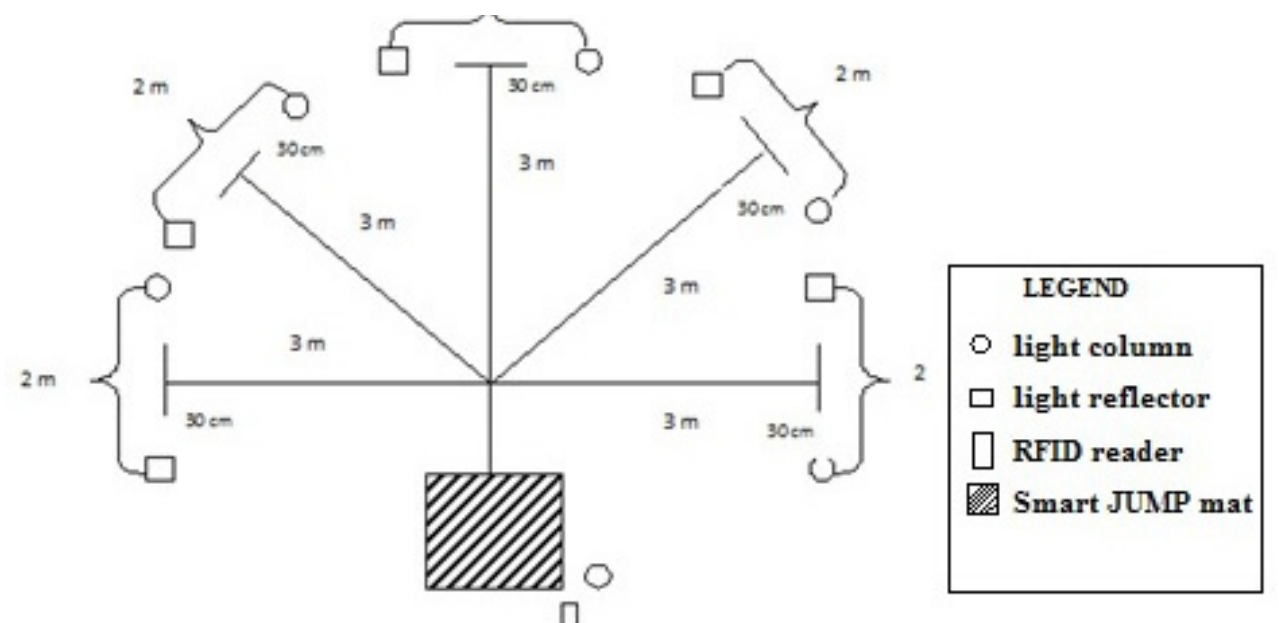

Fig 1. Reactive Shuttle Drill test by Pawlik et al. [59]. 
Statistical analysis was made in Statistica 8.0 statistical package, where basic calculations included: the arithmetic mean, the standard deviation and the coefficient of variation. Analysis of variance (ANOVA) was also carried out for the system in order to verify the relationships between the level of temporalspatial orientation and gender, class and repeated measurement. The statistical significance was set at $\mathrm{p}<0.05$.

\section{RESULTS}

Statistical analysis included a comparison of the results obtained for the level of temporal-spatial orientation in pupils from the experimental and the control classes in the first examination (at the end of the first term of the school year) and the second examination (at the end of the second term of the school year). In the first examination, pupils from the control group obtained better re-sults compared to pupils from the experimental group, with the difference between the results being statistically significant $(p=0.04)$. In the second examination, pupils from the experimental class obtained better results compared to those from the control group. However, the difference between the results obtained in both groups was not statistically significant $(\mathrm{p}=0.87$ ) (Fig. 2) (Tab. 1).

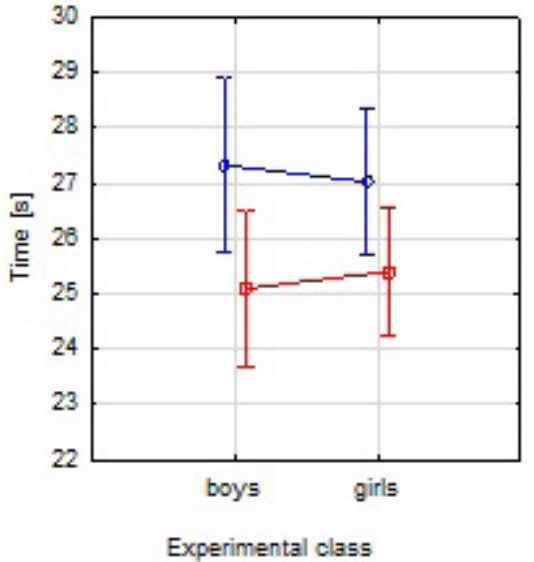

코- Examination 1

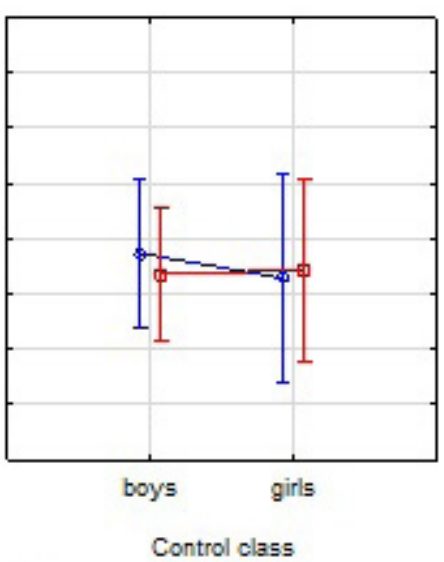

Examination 2

Fig 2. Results obtained by pupils from the experimental and the control classes in the first and second ex-aminations

Table 1. Results obtained for the level of temporal-spatial orientation in the first and second examinations

\begin{tabular}{|c|c|c|c|c|c|c|c|c|}
\hline \multirow[b]{2}{*}{ Examination } & \multirow[t]{2}{*}{ Class } & \multicolumn{3}{|c|}{ Experimental class } & \multicolumn{3}{|c|}{ Control class } & \multirow{2}{*}{$\mathrm{p}$} \\
\hline & & $\bar{X}$ & SD & VC & $\bar{X}$ & SD & VC & \\
\hline \multirow[t]{3}{*}{ Examination 1} & Total & 27.15 & 3.07 & 11.31 & 25.58 & 1.82 & 7.11 & $0.04 *$ \\
\hline & G & 27.03 & 3.41 & 12.61 & 25.28 & 1.99 & 7.87 & 0.14 \\
\hline & B & 27.33 & 2.65 & 9.71 & 25.73 & 1.77 & 6.88 & 0.15 \\
\hline \multirow[t]{3}{*}{ Examination 2} & Total & 25.28 & 2.39 & 9.44 & 25.38 & 2.16 & 8.51 & 0.87 \\
\hline & G & 25.40 & 2.45 & 9.64 & 25.43 & 2.18 & 8.56 & 0.98 \\
\hline & B & 25.10 & 2.40 & 9.56 & 25.36 & 2.23 & 8.78 & 0.81 \\
\hline
\end{tabular}

G - girls, B - boys, $\bar{X}$ - arithmetic mean, SD - standard deviation, CV - coefficient of variation, * - statistically significant at $p<0.05$ 
A comparison of the results obtained for girls and boys from the experimental and the control classes revealed no statistically significant differences. In the first examination, girls obtained better results compared to boys in both classes. In the second examination it turned out that boys had better results (Fig. 3-4).

In the experimental class, pupils obtained better results for the level of temporal-spatial orientation in the second examination, with the difference in the results being statistically significant for both girls $(p=0.05)$ and boys $(p=0.00)$. In the control class, boys improved their results compared to the first examination. However, girls obtained poorer mean results for the time of temporal-spatial orientation in the second examination, with the differences in the results being statistically signifi-cant (see Tab. 1).

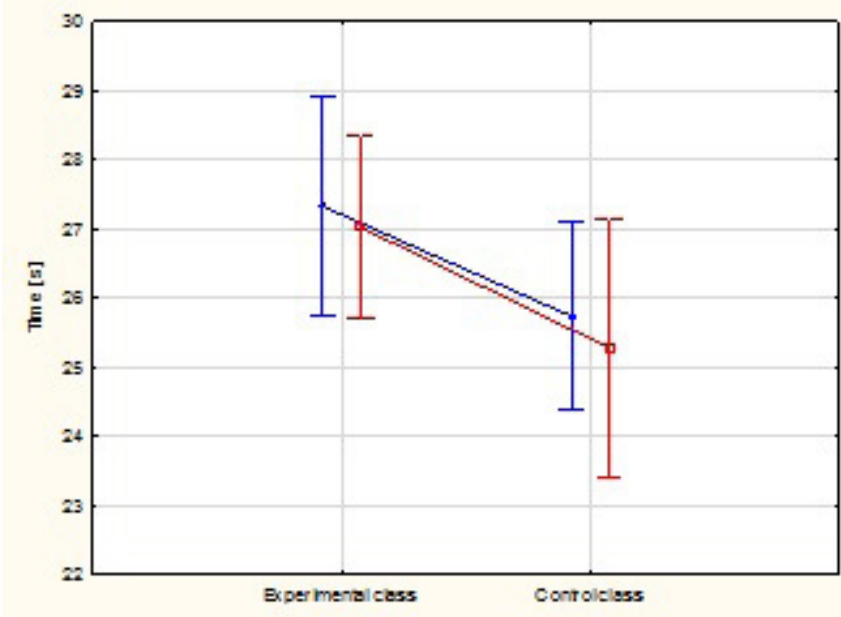

王 Boys 互ors

Fig 3. Results obtained by girls and boys in the first examination.

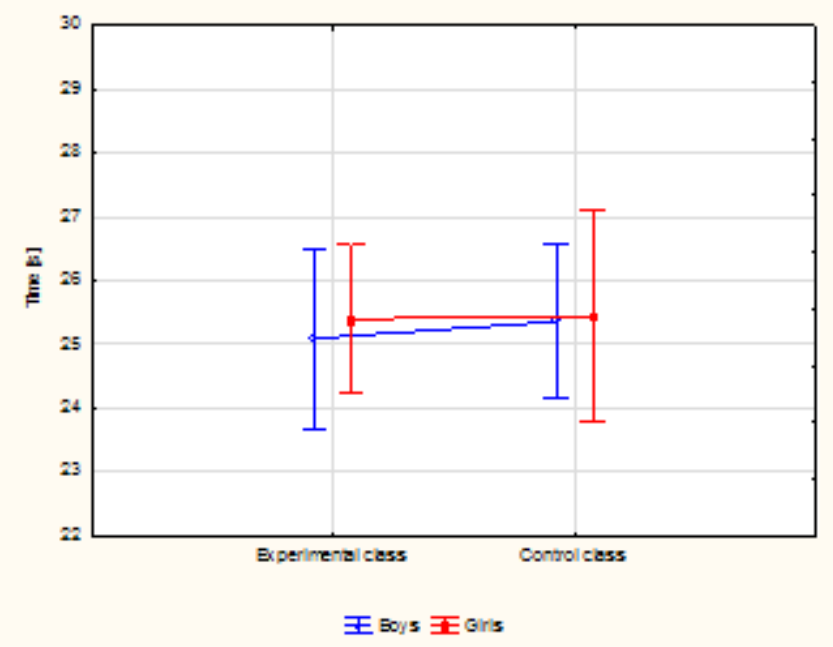

Fig 4. Results obtained by girls and boys in the second examination

Analysis of individual cases of 6-year-oldpupilsshowed that all the pupils obtained better results in the second examination. In the first examination, pupils from both classes obtained poorer results than mean results obtained by 
those who were 7 years old. In the control class and the second examination, pupils also obtained poorer results than mean results for the class. A student from the experimental class ( $\mathrm{x}-1$ ) substantially improved his/her results and obtained better time (24.99 s) compared to his/her older classmates (see Tab. 2).

Table 2. Results obtained by 6-year-old pupils in the first and second examinations

\begin{tabular}{lllll} 
& \multicolumn{2}{l}{ Examination } & Examination 1 & Examination 2 \\
Class/Gender & & & 28.19 & 24.99 \\
\hline Experimental class & X-1 & B & 26.53 & 25.80 \\
\hline Control class & Y-1 & G & 28.24 & 26.91 \\
\cline { 2 - 5 } & Y-2 & G & 27.55 & 26.95 \\
\cline { 2 - 4 } & Y-3 & B & 27.63 & 26.16 \\
\cline { 2 - 4 } & & $\bar{X}$ & & 2 \\
\hline
\end{tabular}

G - girls, B - boys

\section{DISCUSSION}

The aim of the study was to determine the level and changes in the level of temporal-spatial orientation in first-grade pupils from elementary schools who participated in Physical Education classes integrated with subject-related content that used Edubal educational balls.

Since the moment of creation of Edubal educational balls, research has been carried out to find the relationships between Physical Education classes that use Edubal balls and the pupils' physical fitness. The International Physical Fitness Test has been used to diagnose physical fitness. The studies have demonstrated that Physical Education classes that used Edubal educational balls modified physical fitness to the same degree as the classes without using these balls [48, 51-52, 55-56, 60-61].

There is only one publication available in the literature that analysed the relationships between the use of Edubal educational balls with spatial orientation in first-grade pupils from elementary schools [62]. The temporal-spatial orientation was diagnosed by means of the "running to the balls" test [37]. Level of temporal-spatial orientation in pupils from the experimental and control classes was better than in our study. The time of performing the test was similar. However, the results should not be compared due to a different form of performing the test. The Reactive Shuttle Drill test [59] is an objective tool, whereas "running to the balls" test involves substantial intervention of the test supervisor.

Analysis of the related literature showed that the level of temporal-spatial orientation has also been diagnosed by other researchers who used the Reactive Shuttle Drill Fusion Smart System [59, 63]. Pawlik et al. [59] compared the level of temporal-spatial orientation of third-grade pupils from elementary school who were diagnosed with specific learning problems (dyslexia, dysgraphia, dyscalculia) and pupils without such problems. Pupils with specific learning difficulties obtained the mean result of $23.35 \mathrm{~s}$, whereas this value in 
pupils without specific learning problems was 22.62 s. In our study, the mean result obtained for the level of temporal-spatial orientation in pupils in the experimental and control classes was around $25 \mathrm{~s}$. The level of temporal-spatial orientation obtained in our study was similar; however, the results should not be compared with the previous studies due to the pupils' different age.

Rokita et al. [63] diagnosed female and male fencers aged 14 to 16 years. They found that mean results for boys was $18.44 \mathrm{~s}$, whereas this value in girls was $19.41 \mathrm{~s}$. The level of temporal-spatial orientation in pupils analysed by Rokita et al. [63] was better than the results obtained in our study. However, they should not be compared due to the subjects' different age and a different other of the research test stand in the examination. With respect to the results obtained for the level of temporal-spatial orientation, it can be concluded that the level of this ability changes with the subjects' age. Older subjects obtain better results for the level of temporal-spatial orientation.

It was demonstrated that the change in the level of temporal-spatial orientation can be stimulated. The level of this ability might depend on, for example, using specific training methodologies and resources [41-44]. One publication available in the literature documented computer training used to improve the level of spatial abilities [44]. The study showed that all the pupils improved the results of the level of spatial orientation. After the training, pupils with the lowest level of temporal-spatial orientation improved (statistically significantly) their results. However, they did not obtain better results than the subjects with an initially higher level of temporal-spatial orientation. It was found that the lower the initial level of temporal-spatial orientation, the greater its final improve-ment. These findings are consistent with the results obtained in our study. The pupils from the experimental group who obtained statistically significantly $(\mathrm{p}=0.04)$ poorer results in the first experiment improved their results in the second one. In the second experiment, pupils obtained better re-sults compared to the pupils from the control class. However, the difference was not statistically significant this time.

It seems justified to introduce factors and experimental programmes to the educational process in order to improve the level of temporal-spatial orientation in pupils. David [44] proposed spatial orientation training using a computer game. However, it seems that a better method of modifica-tion of temporal-spatial orientation is offered by the use of games and play with Edubal educational balls during Physical Education classes. During Physical Education classes that use such balls pupils are active not only physically but also mentally. Moreover, they improve their physical fitness and develop cognitive skills [48-57, 60-62].

\section{CONCLUSIONS}

1. The level of temporal-spatial orientation in pupils from the experimental class in the first examination oscillated around $27 \mathrm{~s}$ and around $25 \mathrm{~s}$ in the second examination. In the control class, the result in both first and second examination oscillated around $25 \mathrm{~s}$.

2. In the second examination, the pupils from the experimental and the control classes achieved a higher level of temporal-spatial orientation. The differen- 
ce in the results obtained for the level of temporal-spatial orientation in the experimental class was statistically significant between the first and second examinations. Therefore, it seems justified to use Edubal educational balls in Physical Education classes in early school education.

3. Physical Education classes that used Edubal educational balls did not differ in a statistically sig-nificant way between the results obtained for the level of temporal-spatial orientation in first-grade pupils. However, it seems that further studies should be carried out in order to examine the relationships between Physical Education classes using Edubal educational balls with temporal-spatial orientation in pupils over a longer period of time, e.g. the whole school year. The results obtained during a half-year pedagogical experiment improved substantially. Therefore, it can be expected that elongation of the time of the experiment should significantly differentiate the level of temporal-spatial orientation in pupils.

4. Gender seems not to influence the pupils' level of temporal-spatial orientation. In the first exami-nations, girls obtained better results compared to boys, whereas in the second examination this level was found to be better in boys.

Based on the above findings, it seems justified to conduct further studies in order to evaluate the level and possible changes in temporal-spatial orientation in first-grade pupils from elementary school who participate in Physical Education classes that use Edubal educational balls and to search for the relationships between temporal-spatial orientation and school performance of the pupils, particularly in the area of learning reading and writing skills.

\section{REFERENCES}

[1] Borawska K. Umiejetnosci jezykowe dziecka konczacego edukacje wczesnoszkolna [Language skills of the child ending early school education]. Bialystok: Trans Humana; 2004. Polish.

[2] Rozporzadzenie MEN z dnia 23.12.2008 r. Podstawa programowa ksztalcenia ogolnego dla szkol pod-stawowych [Ordinance of the Minister of National Education of 23 December 2008. The core curriculum of general education for primary schools]. Dz.U. z dnia 15.01.2009, nr 4, poz. 17. Polish.

[3] Raczek J. Antropomotoryka, teoria motorycznosci czlowieka w zarysie [Anthropomotorics, the theory of human motor skills]. Warszawa: WL PZWL; 2010. Polish.

[4] Wojcik-Grzyb A. Zdolnosci koordynacyjne warunkiem szybkosci i dokladnosci uczenia sie czytania i pisania [Coordination skills as a condition of speed and accuracy of learning to read and write]. In: Bartoszewicz R, Koszczyc T, Nowak A, editors. Dydaktyka wychowania fizycznego w swietle wspolczesnych potrzeb edukacyjnych [Didactics of physical education in the light of modern educational needs], Wroclaw: WTN; 2005, 335-340. Polish.

[5] Taras H. Physical activity and student performance at school. J Sch Health. 2005;75:214-218.

[6] Piek JP, Baynam GB, Barrett NC. The relationship between fine and gross motor ability, self-perceptions and self-worth in children and adolescents. Hum Movement Sci. 2006;25:65-75.

[7] Uhrich TA, SwalmRL. A pilot study of a possible effect from a motor task on reading performance. Percept Motor Skill. 2007;104:1035-1041.

[8] Budde H, Voelcker-Rehage C, Pietrassyk-Kendziorra S, Ribeiro P, Tidow G. Acute coordinative exercise improves attentional performance in adolescents. Neurosci Lett. 2008; 441(2):219-223.

[9] PiekJP, Dawson L, Smith LM, Gasson N. The role of early fine and gross motor development on later motor and cognitive ability. Hum Movement Sci. 2008;27:668-681.

[10] Son SH, Meisels SJ. The relationship of young children's motor skills to later reading and math achievement. Merrill Palmer Quart. 2006;52:755-778.

[11] Viholainen H, Ahonen T, Lyytinen P, Cantell M, Tolvanen A, Lyytinen H. Early motor development and later language and reading skills in children at risk of familial dyslexia. Dev Med Child Neurol. 2006;48(5):367-73.

[12] Alloway TP. Working memory, reading, and mathematical skills in children with developmental coordina-tion disorder. J Exp Child Psychol. 2007;96:20-36.

[13] Bart O, Hajami D, Bar-Haim Y. Predicting school adjustment from motor abilities in kindergarten. Infant Child Dev. 2007;16:597-615.

[14] Erickson I. Motor skills, attention and academic achievements. An intervention study in school years 1-3. 
Brit Educ Res J. 2008;34:301-313.

[15] Haga M. The relationship between physical fitness and motor competence in children. Child Care Health Dev. 2008;34:329-334.

[16] Chomitz VR, Slining MM, McGowan RJ, Mitchell SE, Dawson GF, Hacker KA. Is there a relationship between physical fitness and academic achievement? Positive results from public school children in the northeastern United States. J Sch Health. 2009;79:30-37.

[17] Eveland-Sayers BM, Farley RS, Fuller DK, Morgan DW, Caputo JL. Physical fitness and academic achievement in elementary school children. J Phys Act Health. 2009;6:99-104.

[18] Niederer I, Kriemler S, Gut J, et al. Relationship of aerobic fitness and motor skills with memory and attention in preschoolers (Ballabeina): A cross-sectional and longitudinal study. BMC Pediatrics. 2011;11:34.

[19] Kwak L, Kremers SP, Bergman P, Ruiz JR, Rizzo NS, Sjostrom M. Associations between physical activity, fitness, and academic achievement. J Pediatr. 2009;155:914-918.

[20] Lopes V, Rodrigues L, Maia JAR, Malina RM. Motor coordination as predictor of physical activity in childhood. Scan J Med Sci Spor. 2009;21:663-669.

[21] Haapala E. Physical Activity, Academic Performance and Cognition in Children and Adolescents. A Systematic Review. BJHPA. 2012;4(1):53-61.

[22] Singh A, Uijtdewillingen L, Twisk JW, van Mechelen W, Chinapaw MJ. Physical activity and performance at school: a systematic review of the literature including a methodological quality assessment. Arch Pediatr Adolesc Med. 2012;166(1):49-55.

[23] Lopes L, Santos R, Pereira B, Lopes VP. Associations between gross motor coordination and academic achievement in elementary school children. Hum Movement Sci. 2013;32:9-20.

[24] Westendorp M, Hartman E, Houwen S, Smith J, Visscher C. The relationship between gross motor skills and academic achievement in children with learning disabilities. Res Dev Disabil. 2011;32:2773-2779.

[25] Westendorp M, Hartman E, Houwen S, Huijgen BCH, Smith J, Visscher C. A longitudinal study on gross motor development in children with learning disorders. Res Dev Disabil. 2014;35:357-363.

[26] Bogdanowicz M. Integracja percepcyjno-motoryczna. Teoria - diagnoza - terapia [The perceptual-motor integration. Theory - diagnosis - therapy]. Warszawa: Centrum Metodyczne Pomocy Psychologiczno-Pedagogicznej; 2000. Polish.

[27] Bogdanowicz M. Ryzyko dysleksji. Problem i diagnozowanie [The risk of dyslexia. Problem and diagnosis]. Gdansk: Harmonia; 2005. Polish.

[28] Beilei L, Lui L, Qu D, von Hofston C. The development of fine motors and their relations to children's academic achievement. Xin Li Xue Bao. 2002;34:494-499.

[29] Rosenblum S, Weiss PL, Parush S. Product and process evaluation of handwriting difficulties. Educ Psychol Rev. 2003;15:41-81.

[30] Feder KP, Majnemer A. Handwriting development, competency and intervention. Dev Med Child Neurol. 2007;49:312-317.

[31] Cahill S. Where Does Handwriting Fit In? Strategies to Support Academic Achievement. Interv Sch Clin. 2009;44:223-228.

[32] Kaiser ML, Albaret JM, Doudin PA. Relationship between visual- motor integration eye-hand coordination and quality of handwriting. Journal of Occupational Therapy, Schools \& Early Intervention. 2009;2:87-95.

[33] Domagala A, Mirecka U. Grafomotoryka u dzieci w wieku 7-13 lat [Graphonomics of children aged 7-13 years]. Lublin: Wydawnictwo Uniwersytetu Marii Curie-Sklodowskiej; 2010. Polish.

[34] van Hoorn J, Maathuis C, Peters L, Hadders- Algra M. Handwriting, visuomotor integration, and neuro-logical condition at school age. Dev Med Child Neurol. 2010;52(10):941-947.

[35] Raczek J, Mynarski W, Ljach W. Ksztaltowanie i diagnozowanie koordynacyjnych zdolnosci motorycznych [Shaping and diagnosis of coordination motor abilities]. Katowice: AWF; 2003. Polish.

[36] Raczek J, Koordynacyjne zdolnosci motoryczne dzieci i mlodziezy: struktura wewnetrzna i zmiennosc osobnicza [Coordination motor abilities of children and young people: internal structure and variability]. Katowice: AWF; 1992. Polish.

[37] Surynt A, Rokita A. Poziom koordynacji wzrokowo-ruchowej dziewczat i chlopcow w wieku 6-7 lat [The level of eye-hand coordination of girls and boys aged 6-7 years]. In: Bartoszewicz R, Koszczyc T, Nowak A, editors. Dydaktyka wychowania fizycznego w swietle wspolczesnych potrzeb edukacyjnych [Didactics of physical education in the light of modern educational needs]. Wroclaw: WTN: 2005, 319-327. Polish.

[38] Zurek G. Zdolnosci motoryczne i cechy somatyczne a osiagniecia szkolne uczniow wiejskich szkol pod-stawowych z Dolnego Slaska [Motor skills and somatic characteristics and educational achievements of students in rural primary schools in Lower Silesia]. Studia i Monografie 105. Wroclaw: AWF; 2012. Polish.

[39] Baenninger M, Newcombe N. Environmental input to the development of sex-related differences in spa-tial and mathematical ability. Learn Individ Differ. 1995; 7(4): 363-379.

[40] Vona G, Massidda M, Cireddu M, Calò C. Genetics and sport performance. Ital J Sport Sci. 2005;12:105-115.

[41] Potter C, Kaufman W, Delacour J, Mokone, M. Three dimensional spatial perception and academic per-formance in engineering graphics: a longitudinal investigation. S Afr J Psychol. 2008;39(1):109-121.

[42] Terlecki MS, Newcombe NS, Little M. Durable and generalized effects on spatial experience on mental rotation: gender differences in growth patterns. Appl Cognitive Psych. 2008;22:996-1013.

[43] Wolbers T, Hegarty M. What determines our navigational abilities? Trends Cogn Sci. 2010;14(3):138-146.

[44] David LT. Training effects on mental rotation, spatial orientation and spatial visualisation depending on the initial level of spatial abilities. Procedia Soc Behav Sci. 2012;33:328-332. 
[45] Nitecka-Walerych A. Rozwoj fizyczny i motoryczny [Physical and motor development]. Zycie Szkoly. 2004;2:94-97. Polish.

[46] Rokita A. The interest in sports activity among first year secondary school students in the years 1995-2001. Kinesiology. 2005;37(1):90-105.

[47] SciSlak M, Rokita A, Popowczak M. Secondary school students' interest in various forms of physical activity. Hum Mov. 2013;14(1):11-19.

[48] Koszczyc T. Pilki edukacyjne "edubal” w ksztalceniu zintegrowanym. Raport z badan [Educational balls "edubal" in integrated education. Research Report], Studia i Monografie 88. Wroclaw: AWF; 2007. Polish.

[49] Rokita A. Rzepa T. Bawiac - ucze sie. Pilki edukacyjne w ksztalceniu zintegrowanym [While playing - I learn. The educational balls "Eduball" in integrated education]. Wroclaw: AWF; 2002. Polish.

[50] Rokita A, Malska-Smialowska A, Babinczuk B. The usage of educational balls "edubal” in the improve-ment of the chosen Polish language skills of third grade primary school students. In: Koszczyc T, Lewandowski M, Starosciak W, editors. Education in a reformed school 6. Wroclaw: WTN; 2007, 131-136.

[51] Cichy I. Proba okreslenia sprawnosci fizycznej z wykorzystaniem pilek edukacyjnych uczniow konczacych I klase szkoly podstawowej [Attempt at determining physical ability with the use of educa-tional balls in pupils completing grade I of primary school]. In: Sekulowicz M, Kruk-Lasocka J, Kul-matycki L, editors. Psychomotoryka: ruch pelen znaczen [Psychomotor studies: Movement full of mean-ing]. Wroclaw: Wydawnictwo Naukowe DSW; 2008, 221-229. Polish.

[52] Rokita A. Zajecia ruchowe z pilkami edukacyjnymi "edubal” w ksztalceniu zintegrowanym a sprawnosc fizyczna oraz umiejetnosci czytania i pisania uczniow [Physical classes with the use of educational balls 'edubal' in integrated education and physical fitness and reading and writing skills of students]. Studia I Monografie 93. Wroclaw: AWF; 2008. Polish.

[53] Krysmann A, Rokita A. Wykorzystanie pilek edukacyjnych "edubal” w ksztalceniu zintegrowanym a nabywanie umiejetnosci czytania i pisania uczniow w klasie III terapeutycznej szkoly podstawowej [Inte-grated education with the use of educational balls 'edubal' and acquisition of reading and writing skills by dyslectic children in grade III from Therapeutic Primary School No 119 in Wroclaw]. Rozprawy Nau-kowe / AWF Wroclaw/. 2011;33:166-177. Polish.

[54] Kaczmarczyk M, Rokita A. Zajecia ruchowe z pilkami edukacyjnymi "edubal" a wiadomosci i umiejetnosci matematyczne uczniow klasy I szkoly podstawowej [Integrated education with the use of educational balls 'edubal' vs. acqusition of mathematical skills in children of first grade in primary school]. Rozprawy Naukowe /AWF Wroclaw/. 2011;34:62-73. Polish.

[55] Krysmann A. Wykorzystanie pilek edukacyjnych "edubal” w ksztalceniu zintegrowanym a umiejetnosci czytania i pisania uczniow z dysleksja. Rozprawa doktorska [The use of educational balls "edubal" in in-tegrated education and reading and writing skills of students with dyslexia. Doctoral thesis]. Wroclaw: AWF; 2012. Polish.

[56] Kaczmarczyk M. Zajecia ruchowe z pilkami edukacyjnymi "edubal” a wiadomosci i umiejetnosci ma-tematyczne uczniow klasy I szkoly podstawowej. Rozprawa doktorska [Movement classes with educa-tional balls "edubal" and mathematical skills of first grade students in primary school. Doctoral thesis]. Wroclaw: AWF; 2013. Polish

[57] Rokita A, Wawrzyniak S, Medrek M. Zajecia ruchowe z pilkami edukacyjnymi “edubal” a umiejetnosc utrzymania pisma w liniaturze przez uczniow klasy I szkoly podstawowej [Movement classes with the use of educational balls 'edubal' and the ability to write in lines in first grade students of elementary school], Rozprawy Naukowe /AWF Wroclaw/. 2013;43:39-45. Polish.

[58] Gruszczyk-Kolczynska E. Komentarz do podstawy programowej edukacji wczesnoszkolnej, Podstawa programowa z komentarzami, tom 1, Edukacja przedszkolna i wczesnoszkolna [Commentary on the core curriculum of early childhood education. Core curriculum with comments, Volume 1, Preschool and Early Education], Dz.U. z dnia 15.01.2009, nr 4, poz. 17; 2009. Polish.

[59] Pawlik D, Rokita A, Cichy I. Orientacja czasowo-przestrzenna uczniow ze specyficznymi trudnosciami w uczeniu sie [Time-space orientation in students with special learning disorders]. Rozprawy Naukowe /AWF Wroclaw/. 2013;43:46-56. Polish.

[60] Cichy I. Sprawnosc fizyczna, ogolna koordynacja ciala i kompetencje edukacyjne uczniow I klasy szkoly podstawowej prowadzonych programem tradycyjnym i nietradycyjnym. Rozprawa doktorska. [Physical fitness, body coordination and educational competence of students of primary school carried out tradi-tional and non-traditional programs. Doctoral thesis]. Wroclaw: AWF; 2010. Polish.

[61] Rokita A, Krysmann A. Zwiazki wykorzystania pilek edukacyjnych "edubal” z wybranymi zdolnosciami motorycznymi uczniow klasy I szkoly podstawowej [Relationships between using 'edubal' balls and some selected body skills of first grade students of the primary school]. Rozprawy Naukowe /AWF Wroclaw/. 2011;35:112-121. Polish.

[62] Rokita A, Kaczmarczyk M. Zwiazki wykorzystania pilek edukacyjnych "edubal” z orientacja w przestrzeni u uczniow klasy I szkoly podstawowej [A relation between the use of educational balls 'edubal' and the spatial orientation of children in primary school]. Rozprawy Naukowe /AWF Wroclaw/. 2011;35:108-111. Polish.

[63] Rokita A, Bronikowski M, Popowczyk M, Cichy I, Witkowski M. Precision and coordination parameters of Polish elite cadet fencers. Med Sport. 2014:67(3):369-381. 